\title{
Temperatures experienced by fresh-cut leafy greens during retail storage and display
}

\author{
W. Brown',a E. Ryser², L. Gorman³ ${ }^{3}$, S. Steinmaus ${ }^{1}$ and K. Vorst ${ }^{4}$ \\ 1Department of Horticulture and Crop Science, California Polytechnic State University, San Luis Obispo, CA \\ 93405, USA; ${ }^{2}$ Department of Food Science and Human Nutrition, Michigan State University, East Lansing, MI \\ 48865, USA; ${ }^{3}$ Finance Department, California Polytechnic State University, San Luis Obispo, CA 93405, USA; \\ ${ }^{4}$ Department of Food Science and Human Nutrition, Iowa State University, Ames, IA 50011, USA.
}

\begin{abstract}
There has been limited published work in the United States on temperature profiling of fresh-cut, bagged leafy greens during their transport, retail storage, and retail display. This study utilized temperature monitors placed in backrooms and display cases at nine supermarkets located in southern California: the Central Coast (Santa Barbara to Los Osos), Greater Los Angeles (Burbank area), and Greater Palm Desert. Sensors were installed midway along each 8-foot display case section containing fresh-cut leafy greens. Monitors were placed at the front and back of shelves and in the lower bin. In storage rooms, sensors were placed 4 feet from the floor in each corner. High and low temperature abuse occurred in retail display cases, with slightly more than $40 \%$ of the sensors indicating temperatures $>7.22^{\circ} \mathrm{C}$, and $17 \%$ of the sensors indicating temperatures $<-0.17^{\circ} \mathrm{C}$, for at least $5 \%$ of the time. Temperatures in storage rooms were rarely too low, but were often too high: slightly more than $58 \%$ of the sensors indicated temperatures $>7.22^{\circ} \mathrm{C}$ more than $5 \%$ of the time, and five sensors measured continuous temperatures $>7.22^{\circ} \mathrm{C}$ for nearly a year. Overall, most temperature abuse of pre-cut leafy greens at the retail level occurred during backroom storage. This study should be expanded to include major grocery chains in cities across the United States in order to verify these results.
\end{abstract}

Keywords: Romaine, lettuce, supermarket, Listeria monocytogenes, Escherichia coli 0157:H7, food safety, backroom

\section{INTRODUCTION}

Food-borne pathogens are a continued public-health and grower-packer concern because of their persistence in processing and distribution environments. Numerous studies have identified Listeria monocytogenes and Escherichia coli 0157:H7 as pathogens of great concern during the postharvest handling of whole and fresh-cut produce (Johnston et al., 2005; FDA, 2006a, 2010, 2014; DeNoon, 2011; Brown et al., 2016). More than 800 illnesses and eight deaths have been associated with the consumption of fresh-cut produce, specifically leafy greens, spinach and lettuce, grown in California (FDA, 2005). Widely distributed in nature, Listeria has received much attention and concern because of its ability to grow at refrigeration temperatures (Junttila et al., 1988; Walker et al., 1990; Todar, 2012; Zeng et al., 2014).

Over the past decade, L. monocytogenes and E. coli 0157:H7 have been implicated in numerous recalls. In 2006, California-grown, baby flat-leaf spinach caused more than 200 cases of E. coli 0157:H7 infection in 28 states, resulting in three deaths and 31 confirmed cases of hemolytic uremic syndrome (FDA, 2006b). In 2011, cantaloupe contaminated with L. monocytogenes caused 147 cases of listeriosis, resulting in 33 deaths and one miscarriage (CDC, 2012). Since 2010, there have been eight recalls due to possible contamination by $L$. monocytogenes (Zeng et al., 2014).

${ }^{\mathrm{a} E}$-mail: wbrown@calpoly.edu 
Growth of E. coli 0157:H7 at refrigeration temperatures has been reported on freshcut leafy greens at $10^{\circ} \mathrm{C}$ and above (Koseki and Isobe, 2005), with decreased populations at $12^{\circ} \mathrm{C}$ after 14 days of storage with shredded lettuce (Abdul-Raouf et al., 1993).

Previous work by Beuchat and Brackett (1990) suggested that, at temperatures below $10^{\circ} \mathrm{C}$, there may not be a substantial risk of growth for L. monocytogenes on shredded lettuce. However, more recent studies by O'Beirne et al. (2015) and Zeng et al. (2014) have suggested growth of L. monocytogenes on shredded lettuce under reduced oxygen atmospheres, with estimated minimum growth thresholds depending on the strain of the pathogen.

Published studies suggest the potential for growth during retail storage and display (Zeng et al., 2014; Brown et al., 2016). Limited published work has been done on retail temperature profiling of fresh-cut leafy greens and bagged salads in the United States (Nunes et al., 2009; Kou et al., 2015). This objective of this study was to monitor and profile the temperature of bagged salads during handling and distribution at retail stores in Southern California. The upper threshold for temperature abuse of $7.2^{\circ} \mathrm{C}$ was chosen based on standard industry practice. A lower limit of $-0.17^{\circ} \mathrm{C}$ was considered an abusive temperature as it is just above the freezing point of lettuce as reported by Cantwell and Suslow (2013) and Hardenburg et al. (1986).

\section{MATERIALS AND METHODS}

From 2011 to 2012, temperature monitors were placed in both cold-storage rooms and display cases at nine locations in three geographic regions of Southern California: the Central Coast (Santa Barbara to Los Osos), Greater Los Angeles (Burbank area), and the Greater Palm Desert. Display cases were monitored for $\sim 2$ months during both summer and winter. The cold storage rooms, located at the back of each store, were monitored continuously for approximately 1 year.

Eight, 60-day Ultra Contact Labels (PakSense, Boise, ID, USA) were installed midway along each 8-foot display case containing fresh-cut, leafy greens. Monitors were placed at the front of shelves 1, 2, 3, 5 and 6, and at the back of each case under shelves 1,3 and 5 (Figure 1a). If a store had multiple display cases containing fresh-cut produce, sensors were installed in each display case using the same protocol. The 60-day Ultra Contact Labels had a 1 minute sampling frequency and were accurate to within $\pm 0.5^{\circ} \mathrm{C}$ between -10 and $30^{\circ} \mathrm{C}$ (http://www.paksense.com/products/ultra-contact).

(a)

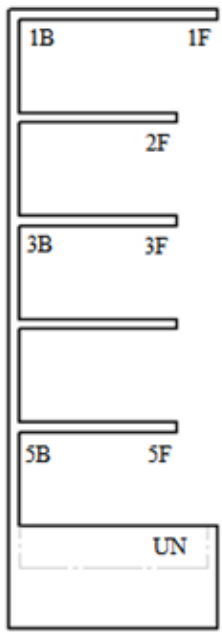

(b)

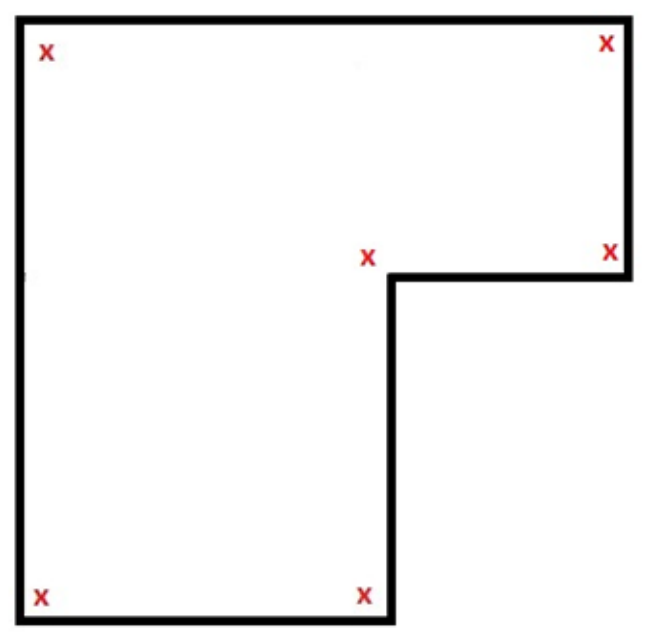

Figure 1. (a) Location of temperature monitors in display cases at retail locations. B, Back; F, front; UN, underneath (salads bags in lower bin). (b) Location of temperature monitors in cold-storage rooms at retail locations: atypical room configuration. 
In the storage rooms, TempTale ${ }^{\circledR} 4$ monitors (Sensitech, Beverly, MA, USA) were placed 4 feet from the floor in each corner. The storage rooms were typically shaped as large rectangles, and only required four sensors; however, in two locations, the storage room was shaped as an "L" and required an additional two sensors (Figure 1b). The TempTale ${ }^{\circledR 4}$ monitors were programmable and, in this study, the monitors were set to a 15-minute sampling frequency.

\section{Data analysis}

Retail data were analyzed using MATLAB (v. 7.0) software (Mathworks, Natick, MA, USA). Each sensor temperature-profile was analyzed for percentage of time, longest uninterrupted interval, and average interval above or below -0.17 or $7.2^{\circ} \mathrm{C}$. The profiles were then compiled to determine overall data trends.

\section{RESULTS}

\section{Display cases}

High-temperature abuse was recorded in all nine of the monitored display cases (Table 1). Ninety-six of the 239 temperature sensors used in this study recorded temperatures above $7.22^{\circ} \mathrm{C}$ for at least $5 \%$ of the total time ( 2 months) that they were installed in the display cases. One sensor recorded temperatures above $7.22^{\circ} \mathrm{C}$ for more than $65 \%$ of the total time. The highest temperature recorded during the study was $27.6^{\circ} \mathrm{C}$. The longest uninterrupted interval above $7.22^{\circ} \mathrm{C}$ was $240 \mathrm{~h}$, or 10 days.

Table 1. Type of abuse recorded at each retail location in southern California.

\begin{tabular}{lccccc}
\hline \multirow{2}{*}{ Location } & \multirow{2}{*}{ Region } & \multicolumn{2}{c}{ Retail display case } & \multicolumn{2}{c}{ Back storage room } \\
\cline { 3 - 6 } & & $<-0.17^{\circ} \mathrm{C}$ & $>7.22^{\circ} \mathrm{C}$ & $<-0.17^{\circ} \mathrm{C}$ & $>7.22^{\circ} \mathrm{C}$ \\
\hline Palm Springs & Southwest Desert & - & $x^{1}$ & - & $\mathrm{x}$ \\
Burbank & South Coast & $\mathrm{x}$ & $\mathrm{x}$ & - & - \\
Palm Desert & Southwest Desert & - & $\mathrm{x}$ & - & $\mathrm{x}$ \\
Los Osos & Central Coast & $\mathrm{x}$ & $\mathrm{x}$ & - & - \\
Palm Springs & Southwest Desert & $\mathrm{x}$ & $\mathrm{x}$ & - & $\mathrm{x}$ \\
Santa Barbara & Central Coast & - & $\mathrm{x}$ & - & $\mathrm{x}$ \\
Burbank & South Coast & $\mathrm{x}$ & $\mathrm{x}$ & - & $\mathrm{x}$ \\
San Luis Obispo & Central Coast & $\mathrm{x}$ & $\mathrm{x}$ & - & $\mathrm{x}$ \\
Burbank & South Coast & - & $\mathrm{x}$ & - & - \\
\hline
\end{tabular}

${ }^{1}$ " $\mathrm{X}$ " indicates that temperatures exceeding the threshold was observed at the location.

Low-temperature abuse was recorded for at least $5 \%$ of the time in five of the nine display cases (Table 1). Forty-one of the 239 temperature sensors recorded temperatures below $-0.17^{\circ} \mathrm{C}$ for at least $5 \%$ of the time ( 2 months) that they were monitored. One sensor recorded temperatures below $-0.17^{\circ} \mathrm{C}$ for more than $86 \%$ of the total time. The lowest temperature recorded was $-2.83^{\circ} \mathrm{C}$. The longest interval below $-0.17^{\circ} \mathrm{C}$ was $14.5 \mathrm{~h}$.

Though not analyzed statistically, a review of the data indicated that temperatures were often too high at the top and too low at the bottom (in the well) of the display cases (data not shown).

\section{Retail storage rooms}

High-temperature abuse was recorded for at least $5 \%$ of the time in six of the nine monitored storage rooms (Table 1). Sixty-five of the 112 temperature sensors recorded temperatures above $7.22^{\circ} \mathrm{C}$ for more than $5 \%$ of the time. Five of the 112 temperature sensors never recorded temperatures below $7.22^{\circ} \mathrm{C}$ for the duration of the study, which was approximately 1 year. The highest temperature recorded was $19.56^{\circ} \mathrm{C}$.

In all nine storage rooms, low-temperature abuse was absent or minimal. No sensor 
recorded temperatures below $-0.17^{\circ} \mathrm{C}$ more than $1 \%$ of the total time that temperatures were monitored.

\section{DISCUSSION}

High-temperature abuse occurred in retail display cases, with slightly more than $40 \%$ of the sensors indicating temperatures above $7.22^{\circ} \mathrm{C}$ for more than $5 \%$ of the time. Lowtemperature abuse occurred as well, with slightly more than $17 \%$ of the sensors indicating temperatures below $-0.17^{\circ} \mathrm{C}$ for at least $5 \%$ of the time. The longest uninterrupted interval above $7.22^{\circ} \mathrm{C}$ was $240 \mathrm{~h}$, and the lowest uninterrupted interval below $-0.17^{\circ} \mathrm{C}$ was $14.5 \mathrm{~h}$. However, subsequent work based, in part, on temperature profiles generated in this study has shown little growth of E. coli 0157:H7 on pre-cut leafy greens during $72 \mathrm{~h}$ simulated retail display, though L. monocytogenes populations increased $\sim 1$ log cfu g-1 during this same period (Zeng et al., 2014).

No significant low-temperature abuse occurred in any of the storage rooms. Data indicated that temperatures in storage rooms were set too high, as slightly more than $58 \%$ of the sensors indicated temperatures $>7.22^{\circ} \mathrm{C}$ more than $5 \%$ of the time. In fact, five of the sensors never indicated a temperature below $7.22^{\circ} \mathrm{C}$, over a period of nearly a year. Subsequent work based, in part, on temperature profiles generated in this study has shown growth of E. coli 0157:H7 and L. monocytogenes of $\sim 3 \log _{\text {cfu }} \mathrm{g}^{-1}$ on pre-cut leafy greens during $72 \mathrm{~h}$ of simulated retail storage (Zeng et al., 2014).

Microbial work based on five representative high-temperature abuse profiles generated from a related transport study (Brown et al., 2016) has shown no growth of E. coli 0157:H7 during 48-52 h of simulated transport, while L. monocytogenes populations increased $\leq 0.6 \mathrm{log}_{\mathrm{cfu} \mathrm{g}}{ }^{-1}$ under the same conditions (Zeng et al., 2014).

\section{CONCLUSIONS}

Microbial work based on abuse profiles generated in a related study found no growth of E. coli 0157:H7 during simulated transport, while L. monocytogenes populations increased by less than $\leq 0.6 \log \mathrm{cfu}^{-1}$. Likewise, there was little growth of $E$. coli $0157: \mathrm{H7}$ on pre-cut leafy greens during $72 \mathrm{~h}$ simulated retail display, though L. monocytogenes populations increased by $\sim 1 \log \mathrm{cfu} \mathrm{g}^{-1}$ during this same period. In contrast, high-temperature abuse was more of a concern in retail storage rooms, and subsequent work has shown growth of $E$. coli 0157:H7 and L. monocytogenes of $\sim 3 \log \mathrm{cfu}^{-1}$ on pre-cut leafy greens during $72 \mathrm{~h}$ of simulated retail storage. These results clearly indicate that more stores in cities across the U.S. should be monitored to better assess the potential for and degree of temperature abuse to which pre-cut-leafy greens are subjected. In addition, transport temperatures from distribution centers to retail receiving docks should be monitored. This will result in a complete temperature profile for pre-cut leafy greens - from processing centers through retail display - which will enable food safety risks for these products to be more accurately assessed.

\section{ACKNOWLEDGEMENTS}

This research was made possible by a United States Department of Agriculture, National Integrated Food Safety Initiative (USDA-NIFSI) grant. The authors wish to express their gratitude to Jeff Leshuk and Sensitech, Inc., for the donation of temperature sensors to support this research.

\section{Literature cited}

Abdul-Raouf, U.M., Beuchat, L.R., and Ammar, M.S. (1993). Survival and growth of Escherichia coli 0157:H7 on salad vegetables. Appl. Environ. Microbiol. 59 (7), 1999-2006. PubMed

Beuchat, L.R., and Brackett, R.E. (1990). Survival and growth of Listeria monocytogenes on lettuce as influenced by shredding, chlorine treatment, modified atmosphere packaging and temperature. J. Food Sci. 55 (3), 755-758 http://dx.doi.org/10.1111/j.1365-2621.1990.tb05222.x.

Brown, W., Ryser, E., Gorman, L., Steinmaus, S., and Vorst, K. (2016). Transit temperatures experienced by freshcut leafy greens during cross-country shipment. Food Contr. 61, 146-155 http://dx.doi.org/10.1016/ 
j.foodcont.2015.09.014.

Cantwell, M., and Suslow, T. (2013). Lettuce, Crisphead: Recommendations for Maintaining Postharvest Quality. http://postharvest.ucdavis.edu/pfvegetable/LettuceCrisphead/.

CDC. (2012). Multistate Outbreak of Listeriosis Linked to Whole Cantaloupes from Jensen Farms, Colorado (Atlanta, GA, USA: Centers for Disease Control and Prevention). http://www.cdc.gov/listeria/ outbreaks/cantaloupes-jensen-farms/082712/.

DeNoon, D.J. (2011). Listeria Prompts Romaine Lettuce Recall. WebMD. http://www.webmd.com/foodrecipes/food-poisoning/20110930/listeria-prompts-romaine-lettuce-recall.

FDA. (2005). FDA Letter to California Firms that Grow, Pack Process or Ship Fresh and Fresh-cut Lettuce, 4 November 2005 (Washington, DC, USA: U.S. Food and Drug Administration) http://www.fda.gov/ Food/GuidanceRegulation/GuidanceDocumentsRegulatory\%20Information/ProducePlantProducts/ucm118911. htm.

FDA. (2006a). FDA Statement on Nunes Lettuce Recall. http://www.fda.gov/NewsEvents/Newsroom/ PressAnnouncements/2006/ucm108765.htm.

FDA. (2006b). FDA Statement on Foodborne E. coli 0157H7 Outbreak in Spinach (Washington, DC, USA: U.S. Food and Drug Administration). http://www.fda.gov/newsevents/newsroom/pressannouncements/2006/ ucm108761.htm.

FDA. (2010). Program Information Manual Retail Food Protection: Recommendations for the Temperature Control of Cut Leafy Greens During Storage and Display in Retail Food Establishments (Washington, DC, USA: U.S. Food and Drug Administration) http://www.fda.gov/food/guidanceregulation/retailfoodprotection/ industryandregulatoryassistanceandtrainingresources/ucm218750.htm.

FDA. (2014). Lettuce: FDA Investigation Summary - Multistate Outbreak of E. coli 0157:H7 Illnesses Linked to Ready-to-Eat Salads (Washington, DC, USA: U.S. Food and Drug Administration). http://www.fda.gov/Food/ RecallsOutbreaksEmergencies/Outbreaks/ucm374327.htm.

Hardenburg, R.E., Watada, A.E., and Yang, C.Y. (1986). The Commercial Storage of Fruits, Vegetables, and Florist and Nursery Stocks. Agriculture Handbook 66 (Washington, DC, USA: USDA).

Johnston, L.M., Jaykus, L.-A., Moll, D., Martinez, M.C., Anciso, J., Mora, B., and Moe, C.L. (2005). A field study of the microbiological quality of fresh produce. J. Food Prot. 68 (9), 1840-1847. PubMed

Junttila, J.R., Niemelä, S.I., and Hirn, J. (1988). Minimum growth temperatures of Listeria monocytogenes and nonhaemolytic Listeria. J. Appl. Bacteriol. 65 (4), 321-327 http://dx.doi.org/10.1111/j.1365-2672.1988.tb01898.x. PubMed

Koseki, S., and Isobe, S. (2005). Growth of Listeria monocytogenes on iceberg lettuce and solid media. Int. J. Food Microbiol. 101 (2), 217-225 http://dx.doi.org/10.1016/j.ijfoodmicro.2004.11.008. PubMed

Kou, L., Luo, Y., Ingram, D.T., Yan, S., and Jurick, W.M., II. (2015). Open-refrigerated retail display case temperature profile and its impact on product quality and microbiota of stored baby spinach. Food Contr. 47, 686-692 http://dx.doi.org/10.1016/j.foodcont.2014.07.054.

Nunes, M.C., Emond, J.P., Rauth, M., Dea, S., and Chau, K.V. (2009). Environmental conditions encountered during typical consumer retail display affect fruit and vegetable quality and waste. Postharvest Biol. Technol. 51 (2),

O'Beirne, D., Gomez-Lopez, V., Tudela, J.A., Allende, A., and Gil, M.I. (2015). Effects of oxygen-depleted atmospheres on survival and growth of Listeria monocytogenes on fresh-cut Iceberg lettuce stored at mild abuse commercial temperatures. Food Microbiol. 48, 17-21 http://dx.doi.org/10.1016/j.fm.2014.11.012. PubMed

Todar, K. (2012). Nutrition and growth of bacteria: effect of temperature on growth. In Todar's Online Textbook of Bacteriology. http://textbookofbacteriology.net/nutgro_5.html.

Walker, S.J., Archer, P., and Banks, J.G. (1990). Growth of Listeria monocytogenes at refrigeration temperatures. J. Appl. Bacteriol. 68 (2), 157-162 http://dx.doi.org/10.1111/j.1365-2672.1990.tb02561.x. PubMed

Zeng, W., Vorst, K., Brown, W., Marks, B.P., Jeong, S., Pérez-Rodríguez, F., and Ryser, E.T. (2014). Growth of Escherichia coli 0157:H7 and Listeria monocytogenes in packaged fresh-cut romaine mix at fluctuating temperatures during commercial transport, retail storage, and display. J. Food Prot. 77 (2), 197-206 http://dx.doi.org/10.4315/0362-028X.JFP-13-117. PubMed 